
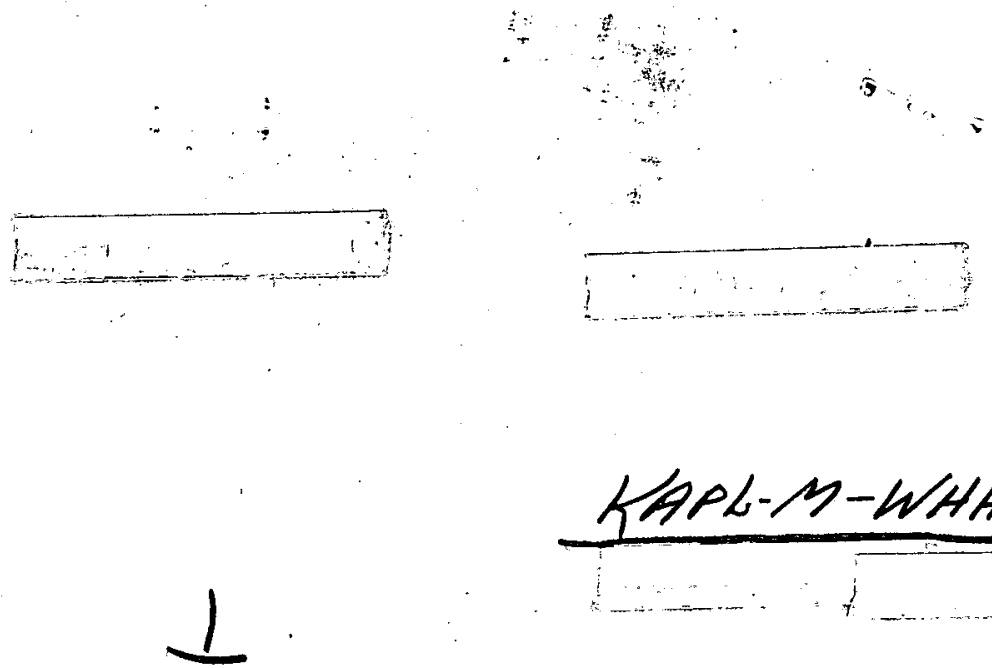

Photostat Price \$

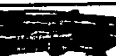

Microfilm Price \$

\title{
$\$$
}

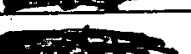

Available from the

Office of Technical Services

Department of Commerce

Washington 25, D. C.

Gereral. III

MROLIS ATOMIC POVER LABCLTRET

Schenestady, ITse Toxy

\section{REACTION RATE OF SOLID SODIUM WITH AIR \\ 85}
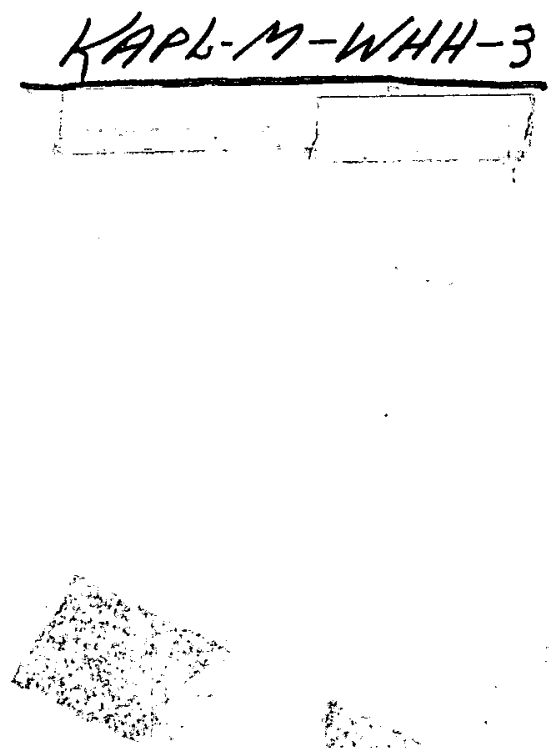

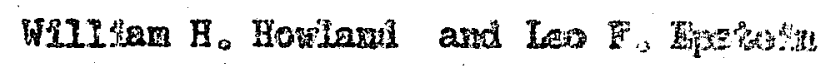

Detobers 19, 1953

\section{LEGAL NOTICE}

This report was prepared as an account of Government sponsored work. Neither the United States, nor the Commission, nor any person acting on behalf of the Commission:

A. Makes any warranty or representation, express or implied, with respect to the accuracy, completeness, or usefulness of the information contained in this report, or that the use of any information, apparatus, method, or process disclosed in this report may not infringe privately owned rights; or

B. Assumes any liabilities with respect to the use of, or for damages resulting from the use of any information, apparatus, method, or process disclosed in this report.

As used in the above, "person acting on behalf of the Commission" includes any employee or contractor of the Commission to the extent that such employee or contractor prepares, handles or distributes, or provides access to, any information pursuant to his employment or contract with the Commission.

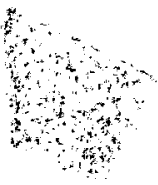

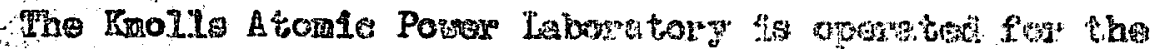

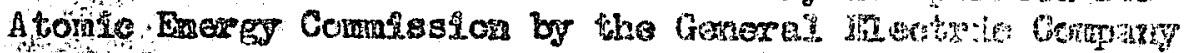

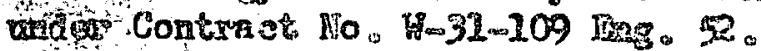

(t)

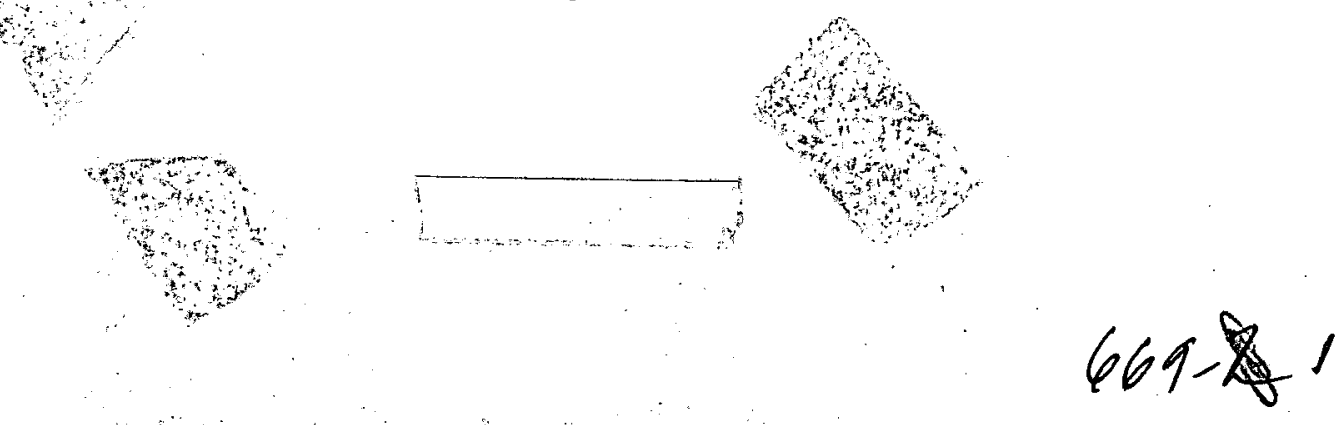




\section{DISCLAIMER}

This report was prepared as an account of work sponsored by an agency of the United States Government. Neither the United States Government nor any agency Thereof, nor any of their employees, makes any warranty, express or implied, or assumes any legal liability or responsibility for the accuracy, completeness, or usefulness of any information, apparatus, product, or process disclosed, or represents that its use would not infringe privately owned rights. Reference herein to any specific commercial product, process, or service by trade name, trademark, manufacturer, or otherwise does not necessarily constitute or imply its endorsement, recommendation, or favoring by the United States Government or any agency thereof. The views and opinions of authors expressed herein do not necessarily state or reflect those of the United States Government or any agency thereof. 


\section{DISCLAIMER}

Portions of this document may be illegible in electronic image products. Images are produced from the best available original document. 


\section{Warning Preliminary Report}

This report was prepared for preliminary use only in the course of work under W31-109 Eng. 52, and the information contained herein may not be correct or in agreement with more recent experimental and operating data. Any values or opinions expressed in the report may be only those of the author, and the General Electric Company makes no representation or warranty (1) as to the value of this report for any purpose or (2) that any use of the report will not infringe the rights of others. 
REACTION RATE OF SOLID SODTUM WTIH AIR

by

WizrIam H. Howland and LeO F。 Epatein

\section{Introduction}

The rate of reaction of sodium with air, and the effect of sodium purity and temperature on this process have recently bees measured here.

It is generally known that chemieal reactiou rates are extremely seasitive to the purity of the reactanta. For example, a freshly eut surface of triply distirled sodirm will not oxidize noarly as rapidiy as will commarcial grade sodium, Distilled Iithfum (99.99\% pure) ean remein in alr for ton (10) hours or longer belore losing its metallie Iusterr ${ }^{(1)}$ but the surface of $99.9 \%$ pure IIthium becomes complotely blackened In a fow seconds a fter exposure to air. It 18 reported (2) that whercas $99.95 \%$ pure zIne dissolves completely in $10 \%$ HCI at room temperature, in the samo time under Identical condition "chemiesily pure" zine (99.99\%) Ioses $53 \%$ by woight and "spectroscopically pure" zine ( $99.999 \%$ or bettere) loses only 0.02\%。

Other factors influeneling the rate of the sodimmin reaction are the mo isture content of the atmosphere and the temperature. of the sample. In this experiment temperatures were intained $30^{\circ} \mathrm{C}, 55^{\circ} \mathrm{C}$ and $80^{\circ} \mathrm{C}$ \& $1^{\circ} \mathrm{C}$ whlle no attempt was modo to control the humldity which averaged about $30 \%$ relatife humldity at room temperature $\left(25^{\circ} \mathrm{C}\right)$; consequently, the measured reaction rate is the sum of the rate of oxidation and the rate of formation of the hydroxide, each influencing the other, with the diffusion of afr through the oxide-hydroxide layer as the rate determining factor. At low temperatures where the vepor pressure of water is low the hydroxide is molst

T. I. F. Epstein and W. $\bar{H}_{\circ}$ Howland Selenee $_{11} 4 / 3$ (Oet, 26, 1951)。

2. Carpenter, H. and Robertson, J. M., Metals, Vol, I Oxfords Oxford Univo Press 585 (1939). 
and forme drops on the the surfece, eventurily falling off。 At higher temperatures, the oxide and hydroxide remain relatively dry. Onless controlled atmospheres are used to study these rates, It Is possible to obsexve only the overall effect of the above conditions.

\section{Exper Imental}

Figure (1) shows one of the three thermostatted furnaces oontaining sodiun filled pyrex "J" tubes of wiform cross sectlon. To "J" tubes wire pleced in each furnace o ono containing triply-distilied sodium and the other containing filtered sodium: Conmerefal briek sodium was melted in a purifled argon fllled dry box and filtered through fritted glass filters into the "J" tubes. The composition of the filtered and distilled sodim is show in Tablo $I_{0}$ Tho osggen content in each caso was assumed to be the equilibrium solubility at about $200^{\circ} \mathrm{C}$ 。

The furnace consists of a $60 \mathrm{~cm}$. length of $10 \mathrm{~cm}$. diameter pyrex tubing open at both onds and heated on the inside by a lamp balb type heating coll. Temperatures were controlled with Cenco bimetallic thermoregulators and neasured with thermometers hanglng vertioally in the center near the exposed sodium aurface. In order to avold the dangor of heating the sodium above its melting polnt ( $99.8^{\circ} \mathrm{C}$ ), fuse wires of $50 \%$ by welght Bi-In alloy (M. P. $94^{\circ} \mathrm{C}$ ) connected in series with the heating circuit were placed in the controlled temperature sone. Changes in the distance between a mark on the upper end of each sodium colum and the $-\left(\mathrm{Na}_{2} \mathrm{O}_{\theta} \mathrm{NaOH}\right.$ ) interface wero measured with a ruler. As timo progressed, the interface became extremely uneven on some of the eamples and great difficulty was encountered in obtaining an average leagth of the colvm. Meagurements were continued out to more than 1000 hours in each case. 
Filtered

Impurit

Fe

0.0008

$\mathrm{Ca}$

61

$$
\mathrm{PO}_{4}
$$

II

Heavy metalo as PB

$\mathrm{SO}_{4}$

0

0.0050
TOTAL 0.0600
$\%$ Ra 99.940

Distilled Na

Impuretit

Percent

58

0.0005

Ca

0.0013

Cl

0.0010

$\mathrm{PO}_{4}$

0.0061

Bม1

0.0001

Co

0.0001

Cr

0.00005

0

0.0050

TOTAL 0.0232

$8 \mathrm{Na} 99.977$ 


\section{Resulte}

The experimental results were PItted to parabolic curves (eharaeteristic of diffusion - IImited processes) of the form $W\left(\mathrm{~g}^{\mathrm{c}} / \mathrm{cm}^{2}\right)=\mathrm{Kt} \mathrm{t}^{1 / 2}$ by the method of least squares. The $\mathrm{K}$ values are given in Table II below. The probable error in $\mathrm{H}$ caleulated from the constants is equal to or loss than $\$ 0,1 \mathrm{~g} / \mathrm{cm}^{2}$. From Plgures 2,3 and 4 it is apparent that at all three temperatures $\left(30^{\circ} \mathrm{C}, 55^{\circ} \mathrm{C}\right.$ and $80^{\circ} \mathrm{C}$ ) filtered sodium has a higher rate of reaction than does the purer distilled sodium, and that the difference betwese the rates decreases with increasing temperature approsehing the same value at the melting point $\left(97,8^{\circ} \mathrm{C}\right)$. From the constants in Table I above, It appears that at the melting point the two rates would be the same to within the rather arude precision of these measurements. If this condition is included in a least-aquare PIt to the rate data (Pfg, 5), the following relations are obtaineds

$$
\begin{aligned}
& \log K_{D}=-0.739-235(1 / T) \text { (DIstilled) } \\
& \log K_{F}=-1.88+190(1 / T) \text { (Filtered) }
\end{aligned}
$$

and the respetive aetivation orgles aros

$$
\begin{aligned}
& \Delta H_{D}=4,07 \cdot \mathrm{Cal} / \mathrm{molo}-{ }^{\circ} \mathrm{C} \text { (Distilled) } \\
& \Delta \mathrm{H}_{\mathrm{F}}=-0.870 \mathrm{~K} \mathrm{CaI} / \mathrm{molo}-\mathrm{O}^{\circ} \mathrm{C} \text { (Filtered) }
\end{aligned}
$$




\section{PABLTIII}

\section{PIITERED}

$I\left({ }^{\circ} \mathrm{C}\right)$

30

55

80

0.097

0.049

0.044

\section{DISTIIED}

$\mathrm{g}\left(\mathrm{g} / \mathrm{cos}^{2}-m \mathrm{~m}^{1 / 2}\right) \quad \mathrm{R}\left(\mathrm{g} / \mathrm{min}^{2}-\mathrm{m}^{1 / 2}\right)$

0.031

0.039

0.038 


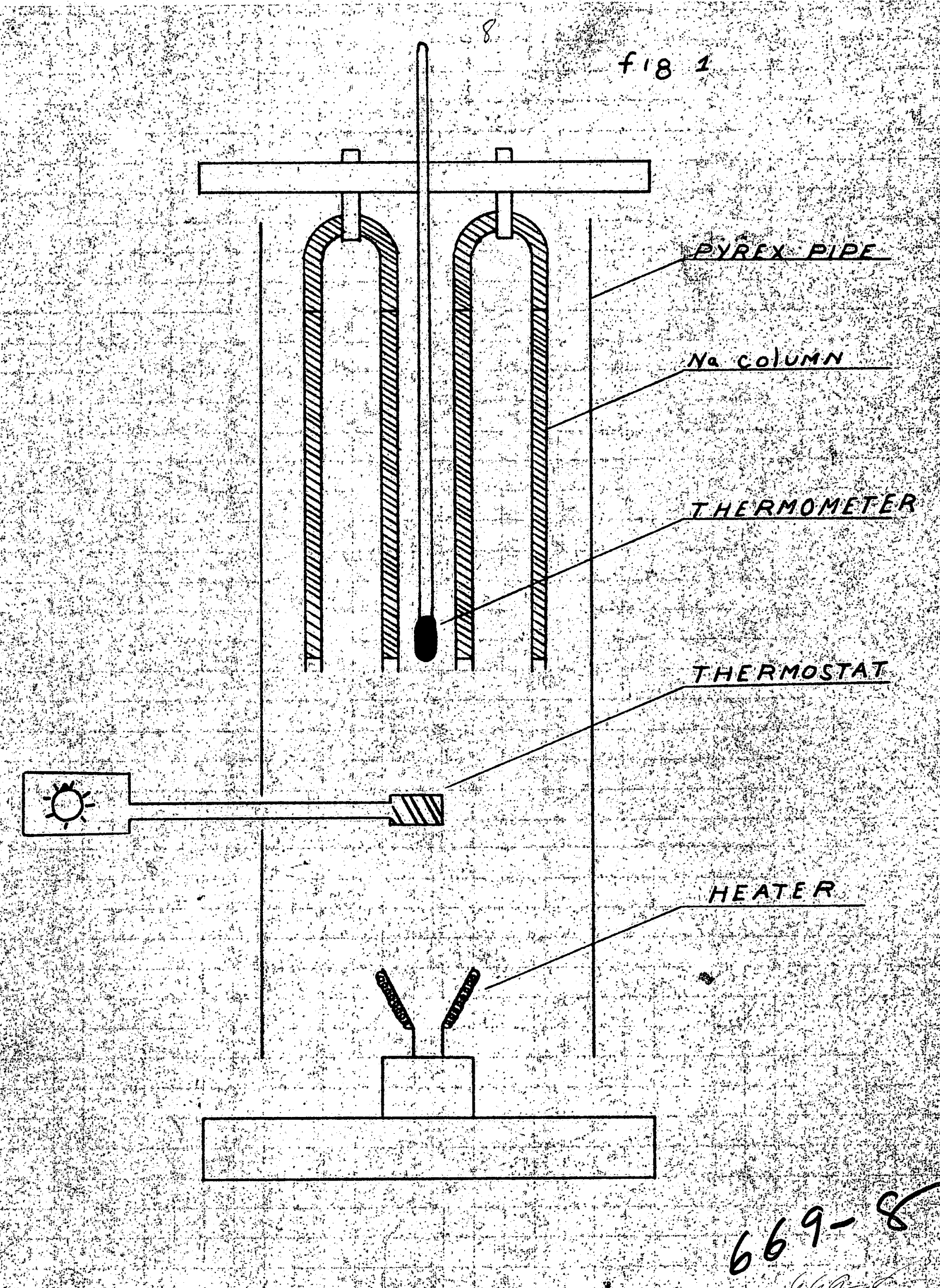




\section{fis.}

\section{$42 x+36$}

fin

0.5
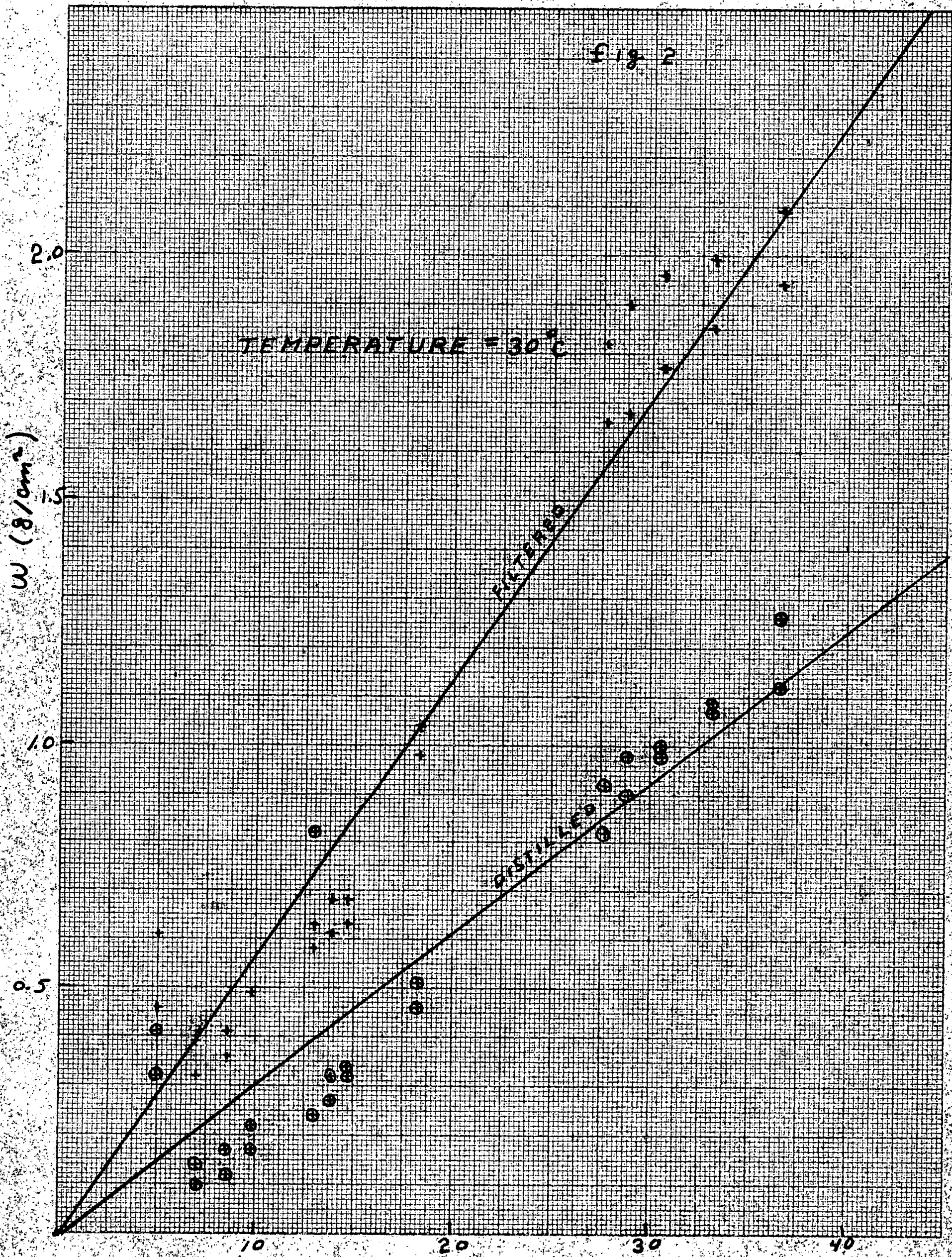
$+1 / 2, \quad 1 / 2$ 


\section{if 12 .}

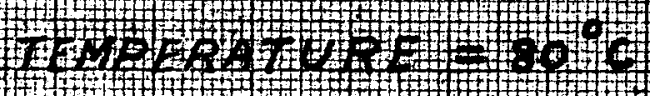

0.5

1.5.

(3)

$2 \times 0$

10
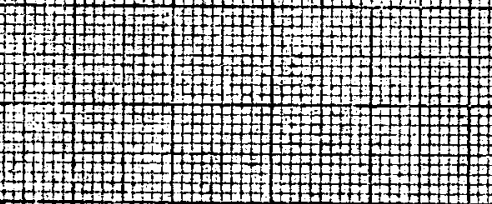


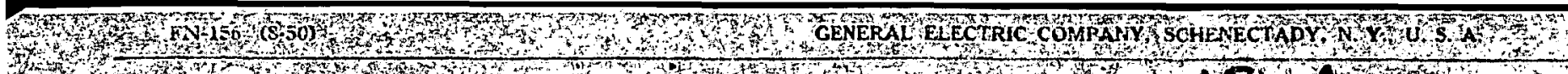
$18: y_{2} 250$ ling

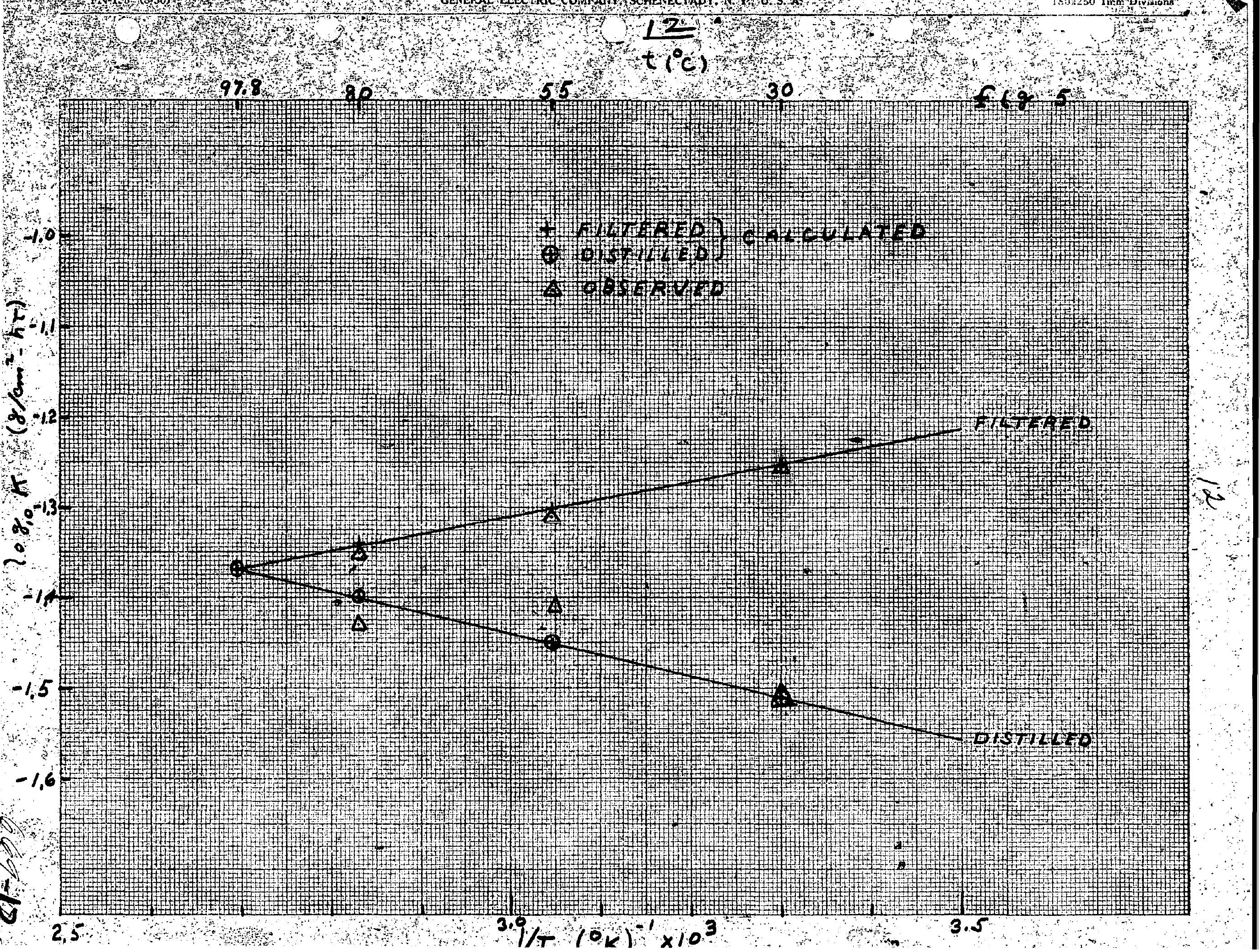

